\title{
HUBUNGAN KEBIASAAN SARAPAN DENGAN KADAR HEMOGLOBIN PADA REMAJA PUTRI (STUDI PENELITIAN DI SMP NEGERI 13 SEMARANG)
}

\author{
Aisyah Nurcita Dewi, Tatik Mulyati*) \\ Program Studi Ilmu Gizi Fakultas Kedokteran Universitas Diponegoro \\ J1.Dr.Sutomo No.18, Semarang, Telp (024) 8453708, Email : gizifk@ undip.ac.id
}

\begin{abstract}
Background: The number of activities being performed by adolescent cause meal time skipping and lack of attention in selecting food composition make them more vurnerable suffering from nutritional issues. Innapropriate food behavior such as skipping breakfast often performed by adolescent girl to get a slimmer body. Breakfast provide 20$25 \%$ energy from daily need in order to fulfill nutrient needs in the morning. Skipping breakfast cause loss of energy and nutrient which needed for hemoglobin $(\mathrm{Hb})$ synthesis.

Method: This is an observational research with cross-sectional approach. Subjects were 54 adolescent girl age 1315 years collected by using consecutive sampling divided into breakfast group and non-breakfast group. Breakfast habit is define by eating breakfast that consist of staple food with side dishes started from woke up in the morning until 10.00 am. Data collected were analyzed using Chi-Square to analyze comparative between variables and Gamma Somers'd to analyze correlative between breakfast habit and $\mathrm{Hb}$.

Result: Both groups were cathegorized as underweight with 48,15\% in breakfast group and 44,4\% in non-breakfast group. Physcial activity from both of group classified as 96,3\% sedentary. As much as 59,26\% and 14,8\% subjects in breakfast and non-breakfast group was sufficient in energy intake. Within 22,2\% subjects in breakfast group had low $\mathrm{Hb}$. This found was higher compared to breakfast group, which only 3,7\% subjects had low Hb.

Conclusion: There's an association between hemoglobin with $p=0.035$ and $r=0.763$. Adolescent girl who skipped breakfast was 6 time in risk having a low hemoglobin compared to those who breakfast regularly.

Keywords: Breakfast; Adolescent girls; Hemoglobin level.
\end{abstract}

\section{ABSTRAK}

Latar Belakang: Banyaknya kegiatan yang dilakukan remaja mengakibatkan waktu makan sering terlewati dan kurang perhatian dalam memilih komposisi makanan, sehingga remaja rentan mengalami masalah gizi. Mendapatkan tubuh yang lebih ramping menyebabkan remaja putri melakukan diet yang tidak tepat, termasuk melewatkan sarapan pagi. Sarapan menyumbang 20-25\% dari kebutuhan energi untuk memenuhi kebutuhan gizi di pagi hari. Melewatkan sarapan menyebabkan hilangnya energi dan zat gizi yang diperlukan untuk sintesis hemoglobin $(\mathrm{Hb})$

Metode: Penelitian cross-sectional dua kelompok tidak berpasangan. Subjek adalah 54 remaja putri berusia 13-15 tahun dibagi menjadi kelompok sarapan dan tidak sarapan, dan dipilih dengan consecutive sampling. Sarapan adalah konsumsi makanan pokok dan lauk pauk sejak bangun tidur sampai jam 10.00. Uji Chi-square digunakan untuk melihat perbedaan antar variabel. Hubungan kebiasaan sarapan dengan kadar Hb dianalisis dengan uji Gamma Somers'd.

Hasil: Subjek pada kedua kelompok memiliki status gizi underweight masing-masing 48,15\% pada kelompok sarapan dan 44,4\% pada kelompok tidak sarapan. Aktivitas fisik kedua kelompok dikategorikan sedentary yaitu 96,3\%. Kecukupan energi pada kelompok sarapan lebih tinggi dibandingkan kelompok tidak sarapan yaitu 59,26\% dan 14,8\%. Kadar Hb rendah lebih banyak ditemukan pada kelompok tidak sarapan yaitu 22,2\% dibandingkan kelompok sarapan yaitu $3,7 \%$.

Simpulan: Terdapat hubungan kebiasaan sarapan dengan kadar hemoglobin, $p=0,035$ dan $r=0,763$. Remaja putri yang tidak memiliki kebiasaan sarapan berisiko 6 kali untuk mempunyai kadar Hb yang rendah dibandingkan dengan remaja putri yang memiliki kebiasaan sarapan.

Kata kunci: Sarapan; Remaja putri; Kadar hemoglobin.

\section{PENDAHULUAN}

Masa remaja merupakan periode yang sangat penting karena terjadi perubahan fisik dan perubahan komposisi tubuh yang menyebabkan peningkatan dalam kebutuhan zat gizi. ${ }^{1}$ Banyaknya kegiatan yang dilakukan oleh remaja mengakibatkan waktu makan sering terlewati dan kurangnya perhatian dalam memilih komposisi makanan yang masuk kedalam tubuh sehingga remaja rentan mengalami masalah gizi. Berdasarkan data Riskesdas tahun 2010, sebanyak masing-masing $54,4 \%$ dan $38,1 \%$ remaja dengan rentang usia 13-15 tahun mengkonsumsi energi dan protein dibawah kebutuhan minimal. ${ }^{2}$

Rendahnya asupan energi dan protein sebagai makronutrien dapat berkontribusi terhadap rendahnya asupan mikronutrien. Asupan makronutrien seperti protein berperan pada 
penyimpanan dan transportasi zat besi. ${ }^{3}$ Selain itu dalam penyerapan zat besi di usus halus juga dibantu oleh Heme Carrier Protein (HCP1) ${ }^{4}$ Menurut Angka Kecukupan Gizi (AKG) 2012 kecukupan protein untuk perempuan berusia 13-15 tahun adalah 69 gram per hari. ${ }^{5}$ Zat besi merupakan komponen utama yang memegang peranan penting dalam pembentukan darah (hemopoiesis) yaitu mensintesis hemoglobin. Kecukupan zat besi untuk perempuan berusia 13-15 tahun adalah $26 \mathrm{mg}$ per hari. ${ }^{5}$ Zink juga diperlukan sebagai komponen salah satu enzim dalam sintesis hemoglobin. Untuk perempuan berusia 13-15 tahun kecukupan zink yang diperlukan adalah $26 \mathrm{mg}$ per hari. ${ }^{5}$

$$
\text { Salah satu faktor yang dapat }
$$

menyebabkan asupan makronutrien dan mikronutrien dibawah kebutuhan minimal adalah perilaku diet yang tidak tepat yang sering dilakukan remaja putri demi menjaga penampilan dan karakteristik fisiknya. ${ }^{6}$ Diet yang terlalu ketat termasuk melewatkan sarapan pagi kerap dilakukan oleh remaja putri untuk mendapatkan bentuk tubuh yang lebih ramping. Remaja putri paling sering melewatkan waktu sarapan dibandingkan dengan waktu makan lainnya. Penelitian observasional di Belgia pada 341 remaja berusia 13-18 tahun menunjukkan bahwa $16,9 \%$ remaja putri dan $13,2 \%$ remaja putra sering melewatkan sarapan. ${ }^{7}$

Sarapan adalah konsumsi makanan pokok dan lauk pauk yang dilakukan semenjak bangun pagi sampai jam 10 pagi untuk memenuhi 20\%$25 \%$ dari kebutuhan energi total dalam sehari yang bertujuan untuk memenuhi kebutuhan zat gizi di pagi hari. ${ }^{8}$ Remaja yang melewatkan sarapan cenderung tidak dapat mengganti kehilangan energi dan zat gizi pada waktu makan lainnya, sehingga sarapan merupakan waktu makan yang penting bagi remaja untuk memenuhi kebutuhan gizi sehari. ${ }^{9}$ Kurangnya asupan zat gizi dapat menyebabkan gangguan pada neurotransmitter yang secara langsung akan berpengaruh pada konsentrasi belajar akibat energi dan prekursor yang dibutuhkan tidak terpenuhi. ${ }^{15}$ Menurut penelitian observasional di Yogyakarta pada 196 murid kelas 5 dan kelas 6 menunjukkan bahwa anak yang tidak teratur melakukan sarapan mempunyai risiko kadar hemoglobin rendah 1,7 kali dibandingkan dengan anak yang teratur sarapan. ${ }^{10}$

Data Badan Pusat Statistik tahun 2011 menunjukkan penduduk usia sekolah di Kota Semarang yang berusia 13-15 tahun merupakan penduduk terbanyak ketiga dalam kelompok penduduk usia sekolah. ${ }^{11}$ Penelitan mengenai hubungan kadar hemoglobin dengan kebiasaan sarapan belum pernah dilakukan khususnya pada remaja pada rentang usia 13-15 tahun.

Berdasarkan uraian diatas, akan diteliti hubungan kadar hemoglobin dengan kebiasaan sarapan dan tidak sarapan pada remaja putri yang akan dilakukan di SMP Negeri 13 Semarang

\section{METODE}

Penelitian ini termasuk dalam ruang lingkup gizi masyarakat yang dilakukan di SMP Negeri 13 Semarang pada bulan Juli 2014. Jenis penelitian adalah penelitian observasional dengan rancangan cross-sectional dua kelompok tidak berpasangan. Populasi target dalam penelitian ini adalah seluruh remaja putri di Kota Semarang, sedangkan populasi terjangkau adalah remaja putri di SMP Negeri 13 Semarang. Perhitungan subjek penelitian dilakukan dengan menggunakan rumus perhitungan sampel kategorik tidak berpasangan. Pengambilan subjek penelitian dilakukan dengan menggunakan metode consecutive sampling, yaitu semua subjek yang datang dan memenuhi kriteria pemilihan dimasukkan dalam penelitian sampai jumlah subjek yang diperlukan terpenuhi. ${ }^{26}$ Didapatkan sebanyak 58 remaja puteri memenuhi kriteria inklusi dan diambil 54 sebagai subjek penelitian kemudian dibagi menjadi kelompok sarapan dan tidak sarapan masing-masing 27 subjek.

Remaja putri yang telah memenuhi kriteria inklusi yaitu remaja berusia 13-15 tahun, bersedia mengisi informed consent, tidak sedang mengonsumsi suplemen dan obat-obatan, tidak sedang sakit dan menjalani puasa pada saat pengambilan data, tidak sedang mengalami menstruasi dan perdarahan pada saat pengambilan darah, tidak mempunyai riwayat penyakit kronik/infeksi, tidak merokok dan tidak memiliki aktivitas fisik dengan intensitas sangat aktif.

Variabel terikat penelitian ini yaitu kadar hemoglobin darah, varibel bebas yaitu kebiasaan sarapan. Kebiasaan sarapan didefinisikan sebagai konsumsi makanan pokok dan lauk pauk yang berlangsung sejak bangun tidur pagi sampai dengan jam 10.00 WIB. Dikatakan mempunyai kebiasaan sarapan bila dalam seminggu melakukan sarapan $>3$ kali dan dikatakan tidak mempunyai kebiasaan sarapan bila tidak sama sekali atau dalam seminggu melakukan makan pagi $\leq 3$ kali dalam seminggu.

Data primer yang dikumpulkan meliputi identitas subjek berupa nama, usia, ada atau tidaknya riwayat penyakit, ada atau tidaknya riwayat mengonsumsi suplemen dan obat-obatan, Identitas ini diperoleh melalui wawancara dengan responden dan dicatat pada formulir identitas 
subyek. Data primer berupa pengukuran antropometri tinggi badan menggunakan mikrotoa kapasitas 2 meter dengan tingkat ketelitian $0,1 \mathrm{~cm}$ dan berat badan ditimbang dengan menggunakan timbangan digital kapasitas $120 \mathrm{~kg}$ dan tingkat ketelitian $0,1 \mathrm{~kg}$. Pengukuran berat badan dan tinggi badan dilakukan setelah pengambilan darah untuk mengukur kadar hemoglobin. Kadar hemoglobin subyek pada saat penelitian diperoleh melalui hasil pemeriksaan laboratorium. Proses pengambilan dan pemeriksaan darah dilakukan oleh petugas laboratorium Permata. Data sekunder penelitian meliputi gambaran umum lokasi penelitian.

Proses pemilihan subyek dilakukan dengan cara melakukan sosialisasi penelitian pada populasi. Setelah itu, dilakukan skrining awal yaitu berupa wawancara kebiasaan sarapan. Peneliti menawarkan kesediaan kepada subjek yang bmemenuhi kriteria untuk menjadi subyek penelitian. Subyek kemudian dibagi menjadi dua kelompok, yaitu kelompok sarapan dan tidak sarapan. Jika bersedia untuk menjadi subyek penelitian, maka subyek tersebut diminta untuk menandatangani lembar informed consent. Setelah itu dilakukan pengambilan darah sampel. Selanjutnya, dilakukan pengukuran tinggi badan dan berat badan untuk mengetahui Indeks Massa Tubuh (IMT). Pengambilan data dilanjutkan dengan pengambilan data food recall selama 3 hari secara tidak berurutan untuk mengetahui gambaran kebiasaan sarapan dan pola makan subyek.

Pengolahan dan analisis data menggunakan program SPSS (Statistical Package
For Social Science) versi 16. Status Gizi berdasarkan Indeks Massa Tubuh (IMT) dikategorikan menggunakan klasifikasi IMT menurut World Health Organization (WHO) 2005 yaitu underweight berat $<17 \mathrm{~kg} / \mathrm{m}^{2}$, underweight ringan $17-18,5 \mathrm{~kg} / \mathrm{m}^{2}$, normal $18,6-25 \mathrm{~kg} / \mathrm{m}^{2}$, overweight $25,1-27 \mathrm{~kg} / \mathrm{m}^{2}$, obesitas $>27 .{ }^{18}$ Kadar hemoglobin dikategorikan menggunakan klasifikasi WHO tahun 2011 yaitu kadar hemoglobin normal pada usia 13-15 tahun adalah $12 \mathrm{gr} / \mathrm{dl} .{ }^{31}$ Data asupan makan dianalisis menggunakan program Nutrisurvey, dibandingkan dengan menurut Angka Kecukupan Gizi (AKG) individu 2012 dan dikategorikan menurut tingkat asupan gizi menurut Departemen Kesehatan 2002 yaitu kurang <90\% dan baik $90-120 \%{ }^{5,19}$ Aktivitas fisik dikategorikan menggunakan tabel aktivitas fisik yang diadaptasi dari Committee Refference Dietary Intake tahun 2005 yaitu sedentary 1,0-1,39, low active 1,4-1,59, aktif 1,6-1,89 dan sangat aktif >1,9. ${ }^{29}$ Uji komparatif Chi-Square digunakan untuk melihat perbedaan status gizi dan aktivitas fisik antara kelompok sarapan dan tidak sarapan. Hubungan kebiasaan sarapan dengan kadar hemoglobin dianalisis dengan uji korelatif Gamma Somers' $d .{ }^{12}$

\section{HASIL PENELITAN}

\section{Gambaran umum subjek penelitian}

Gambaran umum subjek penelitian terdiri dari gambaran status gizi, aktivitas fisik, dan asupan makan disajikan dalam tabel 1 dan tabel 2.

\begin{tabular}{|c|c|c|c|c|c|}
\hline \multirow[t]{2}{*}{ Karakteristik Subjek } & \multicolumn{2}{|c|}{ Sarapan $(n=27)$} & \multicolumn{2}{|c|}{$\begin{array}{c}\text { Tidak Sarapan } \\
(\mathbf{n}=27)\end{array}$} & \multirow[b]{2}{*}{$p$} \\
\hline & $\mathbf{n}$ & $\%$ & $\mathbf{n}$ & $\%$ & \\
\hline Status gizi (IMT) & & & & & $0.910 *$ \\
\hline Underweight berat $\left(<17 \mathrm{~kg} / \mathrm{m}^{2}\right)$ & 6 & $22,22 \%$ & 6 & $22,22 \%$ & \\
\hline Underweight ringan $\left(17-18,5 \mathrm{~kg} / \mathrm{m}^{2}\right)$ & 7 & $25,93 \%$ & 6 & $22,22 \%$ & \\
\hline Normal $\left(18,6-25 \mathrm{~kg} / \mathrm{m}^{2}\right)$ & 11 & $40,74 \%$ & 11 & $40,74 \%$ & \\
\hline Overweight $\left(25,1-27 \mathrm{~kg} / \mathrm{m}^{2}\right)$ & 1 & $3,7 \%$ & 1 & $3,71 \%$ & \\
\hline Obesitas $\left(>27 \mathrm{~kg} / \mathrm{m}^{2}\right)$ & 2 & $7,41 \%$ & 3 & $11,11 \%$ & \\
\hline Aktivitas Fisik & & & & & $1^{*}$ \\
\hline Sedentary & 26 & $96,3 \%$ & 26 & $96,3 \%$ & \\
\hline Aktif & 1 & $3,7 \%$ & 1 & $3,7 \%$ & \\
\hline
\end{tabular}

Sebagian besar subjek pada dua kelompok mempunyai kategori status gizi yang kurang atau underweight dengan persentase total baik tingkat ringan maupun berat masing-masing $48,15 \%$ pada kelompok sarapan dan 44,4\% pada kelompok tidak sarapan. Aktivitas fisik pada kedua kelompok hampir seluruhnya termasuk dalam kategori sedentary. 
Tabel 2. Gambaran umum subjek berdasarkan asupan zat gizi

\begin{tabular}{lcccc}
\hline Karakteristik Subjek & \multicolumn{2}{c}{ Sarapan $(\mathbf{n}=\mathbf{2 7})$} & \multicolumn{2}{c}{ Tidak Sarapan $(\mathbf{n}=\mathbf{2 7})$} \\
\cline { 2 - 5 } & $\mathbf{n}$ & $\mathbf{\%}$ & $\mathbf{n}$ & $\mathbf{\%}$ \\
\hline Asupan Zat Gizi & & & & \\
Asupan Energi & 11 & $40,74 \%$ & 23 & $85,2 \%$ \\
Kurang (<90\%) & 16 & $59,26 \%$ & 4 & $14.8 \%$ \\
Baik(90-120\%) & & & & \\
Asupan Protein & 14 & $51,85 \%$ & 23 & $85,2 \%$ \\
Kurang (<90\%) & 13 & $48.15 \%$ & 4 & $14.8 \%$ \\
Baik (90-120\%) & & & & \\
Asupan Zat Besi & 27 & $100 \%$ & 27 & $100 \%$ \\
Kurang (<90\%) & - & & - & \\
Baik (90-120\%) & & & & \\
Asupan Zink & 27 & $100 \%$ & 27 & $100 \%$ \\
Kurang (<90\%) & - & & - & \\
Baik (90-120\%) & & &
\end{tabular}

Asupan energi pada kelompok sarapan sebagian besar subjek yaitu dikategorikan baik yaitu sebesar $59,26 \%$, tetapi asupan protein, zat besi dan zink pada sebagian besar subjek dikategorikan kurang. Pada kelompok tidak sarapan asupan energi, protein, zat besi maupun zink pada sebagian besar subjek dikategorikan kurang.

Tabel 3. Kebiasaan sarapan dengan kadar hemoglobin

\begin{tabular}{cccccc}
\hline Kategori & \multicolumn{2}{c}{ Kadar Hemoglobin } & Total & $\boldsymbol{p}$ & r \\
\hline \multicolumn{7}{c}{ Rendah } & Normal & & & \\
\hline Tidak Sarapan & 6 & 21 & 27 & $0,035^{*}$ & 0.763 \\
Sarapan & 1 & 26 & 27 & & \\
\hline Total & 7 & 47 & 54 & & \\
\hline
\end{tabular}

Tabel 3 menunjukkan kadar hemoglobin yang rendah lebih banyak ditemukan pada kelompok tidak sarapan yaitu 6 orang $(22,2 \%)$ dibandingkan dengan kelompok sarapan yaitu 1 orang $(3,7 \%)$

\section{Hubungan kebiasaan sarapan dengan kadar hemoglobin}

Hasil uji statistik menunjukkan ada hubungan antara kebiasaan sarapan dengan kadar hemoglobin dengan $p$ value $=0,035$ atau $\mathrm{p}<0,05$. Koefisien relasi 0,763 menunjukkan hubungan yang kuat karena nilai $\mathrm{r}$ termasuk pada kategori 0,60 0,799 .

Rasio prevalens menunjukkan perbandingan antara jumlah subjek pada kelompok sarapan dan tidak sarapan yang mempunyai kadar hemoglobin rendah. Nilai rasio prevalens lebih dari satu menunjukkan bahwa variabel merupakan faktor risiko untuk mempunyai kadar hemoglobin yang rendah. Pada penelitian ini didapatkan rasio prevalens lebih dari satu yaitu sebesar 6 kali. Artinya remaja putri yang tidak memiliki kebiasaan sarapan berisiko 6 kali lebih besar untuk mempunyai kadar hemoglobin yang rendah dibandingkan dengan subjek yang memiliki kebiasaan sarapan.

\section{PEMBAHASAN}

Jumlah subjek dalam penelitian ini adalah 27 orang masing-masing pada kelompok sarapan dan tidak sarapan yang memenuhi kriteria inklusi. Subjek penelitian merupakan remaja putri Sekolah Menengah Pertama (SMP) dengan rentang usia 1315 tahun.

Status gizi pada kedua kelompok sebagian besar dikategorikan underweight baik tingkat ringan maupun berat dengan masing-masing $48,15 \%$ pada kelompok sarapan dan $44,4 \%$ pada kelompok tidak sarapan. Status gizi merupakan gambaran keseimbangan antara asupan zat gizi dengan kebutuhan, apabila hal ini tidak tercapai akan muncul masalah gizi seperti status gizi kurang dan status gizi lebih. ${ }^{13}$ Beberapa faktor yang dapat menyebabkan status gizi kurang antara lain kurangnya asupan zat gizi yang berlangsung secara terus menerus, meningkatnya kebutuhan zat gizi serta gangguan penyerapan dan transportasi zat gizi. ${ }^{14}$

Aktivitas fisik pada kelompok sarapan dan tidak sarapan sebanyak 96,3\% tergolong dalam kategori sedentary dan 3,7\% dalam kategori aktif. Menonton televisi dan berjalan ringan merupakan aktivitas fisik yang banyak dilakukan pada remaja 
putri dengan kategori sedentary. Jenis aktivitas fisik ringan yang dilakukan selama 1-3 jam dapat membakar kalori 80-160 kkal/jam. ${ }^{16}$ Olahraga dengan intensitas ringan sampai sedang seperti berjalan menggunakan lemak atau protein sebagai bahan bakar untuk kontraksi otot. ${ }^{28}$

Kecukupan energi pada kelompok sarapan lebih tinggi bila dibandingkan dengan kelompok tidak sarapan. Pada kelompok tidak sarapan, subjek yang dikategorikan asupan energinya baik adalah $14,8 \%$, sementara asupan energi pada sebagian besar subjek kelompok sarapan yang dikategorikan baik yaitu $59,26 \%$. Sumber energi yang banyak dikonsumsi dari kedua kelompok antara lain makanan pokok seperti nasi, mie, lauk pauk seperti daging ayam dan telur. Konsumsi makanan ringan seperti chiki, coklat, biskuit serta gorengan lebih banyak ditemukan pada kelompok tidak sarapan. Sarapan berkontribusi dalam meningkatkan kecukupan energi dengan menyumbang sebanyak 20-25\%, apabila sarapan terlewati maka akan terjadi kehilangan zat gizi yang tidak dapat digantikan pada waktu makan lainnya. ${ }^{9,17}$

Asupan protein, zat besi dan zink pada kedua kelompok sebagian besar dikategorikan kurang. Asupan protein pada kedua kelompok lebih banyak bersumber dari protein hewani seperti daging ayam, telur, ikan dan susu. Protein hewani memiliki nilai biologis yang lebih tinggi karena mengandung asam amino esensial yang lengkap bila dibandingkan dengan protein nabati. ${ }^{21}$ Sebagian besar subjek pada kedua kelompok mengkonsumsi daging sapi, daging ayam, sayuran hijau, kerang, dan produk susu sebagai sumber zat besi maupun zink. ${ }^{22}$ Pada kelompok sarapan dan tidak sarapan sumber zat gizi tersebut memang telah dikonsumsi, tetapi kuantitasnya belum memenuhi kebutuhan yang dianjurkan. Dalam sehari asupan protein, zat besi maupun zink hanya mencapai masing-masing 30-50 gram, 3-9 gram, dan 3-6 gram.

Kadar hemoglobin rendah ditemukan lebih banyak pada kelompok tidak sarapan yaitu $22,2 \%$, sedangkan pada kelompok sarapan yaitu $3,7 \%$. Hasil uji korelasi Gamma Somers'd menunjukkan adanya hubungan kebiasaan sarapan dengan kadar hemoglobin dengan arah korelasi yang kuat yaitu $p=0,035$ dan $\mathrm{r}=0,763$.

Rasio prevalens menunjukkan perbandingan antara jumlah subjek pada kelompok sarapan dan tidak sarapan yang mempunyai kadar hemoglobin yang rendah. Dari perhitungan rasio prevalens didapatkan nilai 6 . Subjek yang tidak memiliki kebiasaan sarapan berisiko 6 kali lebih besar untuk mempunyai kadar hemoglobin yang rendah dibandingkan dengan subjek yang memiliki kebiasaan sarapan. Hal ini sejalan dengan penelitian observasional yang dilakukan pada 96 siswi di Kulon Progo yang menunjukkan bahwa terdapat hubungan antara frekuensi sarapan dengan kadar hemoglobin dengan faktor risiko kadar hemoglobin menjadi rendah pada sampel yang jarang melakukan sarapan adalah 3,07 kali lebih besar dibandingkan dengan sampel yang rutin melakukan sarapan. ${ }^{25}$ Menurut penelitian observasional di Yogyakarta pada 196 murid kelas 5 dan kelas 6 juga menunjukkan bahwa anak yang tidak teratur melakukan sarapan mempunyai risiko kadar hemoglobin rendah 1,7 kali dibandingkan dengan anak yang teratur sarapan. ${ }^{10}$

Salah satu faktor yang dapat mempengaruhi kadar hemoglobin adalah asupan zat gizi. Kurangnya asupan energi yang bersumber dari makronutrien dan mikronutrien akibat melewatkan sarapan dapat berkontribusi terhadap rendahnya kadar hemoglobin. Energi dibutuhkan dalam berbagai proses fisiologis tubuh, sehingga apabila asupan energi kurang dan terjadi secara terusmenerus akan terjadi pemecahan protein sebagai sumber energi. ${ }^{30}$ Protein diperlukan sebagai bahan awal sintesis heme yaitu asam amino glisin. ${ }^{21}$ Ketersediaan glisin yang rendah menyebabkan heme menjadi terbatas. Protein juga berperan dalam penyerapan, penyimpanan zat besi serta transportasi zat besi. ${ }^{4}$

Asupan zat besi yang rendah tidak langsung menimbulkan gangguan seperti turunnya kadar hemoglobin secara cepat. Pada tahap pertama terjadi deplesi zat besi yang mengakibatkan berkurangnya cadangan zat besi yang tersimpan pada hati, sumsum tulang dan otot dalam bentuk ferritin. ${ }^{23,27}$ Pada tahap kedua terjadi deplesi zat besi yang lebih besar. Asupan yang cukup atau suplementasi dapat mencegah terjadinya gangguan dan penyakit pada tahap ini. Tahap ketiga ditandai dengan rendahnya cadangan zat besi. Pada tahap ini belum dijumpai anemia dengan indikator kadar hemoglobin yang rendah. Tahap keempat ditandai dengan kadar hemoglobin yang rendah sebagai salah satu indikator adanya anemia. ${ }^{24}$

Zink terdapat dalam enzim gammaaminoleulinic yang berperan dalam sintesis heme yang diperlukan untuk pembentukan hemoglobin. ${ }^{20}$ Apabila asupan zink tidak memenuhi maka pembentukan hemoglobin menjadi terganggu.

\section{SIMPULAN}

Kadar hemoglobin yang rendah lebih banyak ditemukan pada kelompok tidak sarapan dibandingkan dengan kelompok sarapan yaitu masing-masing $22,2 \%$ dan $3,7 \%$. Terdapat 
hubungan antara kebiasaan sarapan dengan kadar hemoglobin dengan nilai $p=0,035$ dan koefisien relasi 0,763. Rasio prevalens dengan nilai 6 menunjukkan subjek yang tidak memiliki kebiasaan sarapan berisiko 6 kali lebih besar untuk memiliki kadar hemoglobin rendah dibandingkan dengan subjek yang memiliki kebiasaan sarapan.

\section{SARAN}

1. Pemberian edukasi secara berkala kepada remaja putri dan penyedia makanan tentang sarapan yang baik adalah yang mengandung 20 $25 \%$ energi dari total kebutuhan sehari dengan mengkonsumsi makanan seperti susu, sereal dan roti lapis (sandwich) dalam rangka mencegah rendahnya kadar hemoglobin.

2. Penelitian lebih lanjut mengenai hubungan asupan zat gizi dan konsentrasi belajar dengan kadar hemoglobin.

\section{DAFTAR PUSTAKA}

1. Alam N et al .2010. Nutritional Status, Dietary Intake, and Relevant Knowledge of Adolescent Girls in Rural Bangladesh. J Health Popul Feb;28(1):86-94 ISSN 1606-0997.

2. Departemen Kesehatan RI. LAPORAN RISKESDAS 2010. Badan Penelitian dan Pengembangan Kesehatan Republik Indonesia. Jakarta; 2010.

3. Brox et al. 2003. Hemoglobin, Iron, Nutrition and Life-Style Among Adolescents in a Coasral and Inland Community In Northern Norway. International Journal of Circumpolar Health 62:2.

4. Scheers, Natalie. 2013. Regulatory Effects of $\mathrm{Cu}$, $\mathrm{Zn}$, and $\mathrm{Ca}$ on $\mathrm{Fe}$ Absorption: The Intricate Play between Nutrient Transporters. Nutrients 5, 957970.

5. Hardinsyah, Hadi Riyadi, Victor Napitupulu. 2012. Kecukupan Energi, Lemak, Dan Karbohidrat. Widyakarya nasional pangan dan gizi X Jakarta 2012. Jakarta: LIPI.

6. Foo et al. 2004. Iron status and dietary iron intake of adolescents from a rural community in Sabah Malaysia. Asia Pac. J. Clin. Nutr. 13(1): 48-55.

7. Matthys et al. 2007. Breakfast habits affect overall nutrient profiles in adolescents. Public Health Nutrition 10(4), 413-421.

8. Perdana, Fachrudin, Hardinsyah. 2013. Analisis Jenis, Jumlah, Dan Mutu Gizi Konsumsi Sarapan Anak Indonesia. Jurnal Gizi dan Pangan, 8(1): 39-46.

9. Rampersaud et al.2005. Breakfast Habits, Nutritional Status, BodyWeight, and Academic Performance in Children and Adolescents. $J A m$ Diet Assoc 105:743-760.

10. Kurniasari, Rita. 2005. Hubungan frekuensi dan asupan gizi makan pagi dengan kadar Hemoglobin $(\mathrm{Hb})$ darah dan konsentrasi di Sekolah pada murid kelas V dan VI SDN Jetis I dan SDN Jetishardjo I Yogyakarta. Tesis Ilmu Kesehatan Masyarakat Universitas Gadjah Mada.

11. Badan Pusat Statistik. Penduduk Usia Sekolah Menurut Kabupaten/Kota dan Kelompok umur. Diakses

dari

http://jateng.bps.go.id/index.php?option=com cont ent\&view=article\&id=619:04-01$01 \&$ catid $=47:$ sosial $-2012 \&$ Itemid $=88$

12. Dahlan, Sopiyudin. 2011. Statistik Untuk Kedokteran Dan Kesehatan. Jakarta: Salemba Medika.

13. Principles Of Nutrition. Diunduh dari http://downloads.lww.com/wolterskluwer_vitalstre am com/sample content/9780781766517_Dudek/Chapter1.pdf

14. White Jane, Peggi Guenter, Gordon Jensen, Ainsley Malone, Marsha Schofield. 2012. Consensus Statement of the Academy of Nutrition and Dietetics/American Society for Parenteral and Enteral Nutrition: Characteristics Recommended for the Identification and Documentation of Adult Malnutrition (Undernutrition). J Acad Nutr Diet 112:730-738.

15. Müller et al. 2008. Influence of Having Breakfast on Cognitive Performance and Mood in 13-to 20year old High School Students: Results of a Crossover Trial. Pediatrics Volume 122, Number 2

16. Agoes D, Maria Poppy. 2003. Mencegah dan Mengatasi Kegemukan Pada Balita. Jakarta: Puspa Swara.

17. Cueto Santiago. 2001. Breakfast and dietary balance: the enKid Study. Public Health Nutrition: 4(6A), $1429 \pm 1431$

18. WHO. Appropriate body-mass index for Asian populations and its implications for policy and intervention strategies. Public Health. 2004

19. Anggraeni, Chynthia. 2012. Asuhan Gizi (Nutritional Care Process). Yogyakarta: Graha Ilmu.

20. Gallagher, Margie. 2004. The Nutrients and Their Metabolism. In: Mahan LK, Stump. Krause's foof, nutrition, and diet therapy. 11th ed. Philadelphia: Saunders.

21. Hoffman Jay, Michael J. Falvo. 2004. ProteinWhich Is Best? Journal of Sports Science and Medicine 3, 118-130.

22. Ida Tidemann-Andersen. 2011. Iron and zinc content of selected foods in the diet of schoolchildren in Kumi district, east of Uganda: a cross-sectional study. Nutrition Journal.

23. Sean Lynch. $2007 . \quad$ Iron Metabolism. Switzerland:Sight and Life Press

24. Stopler, Tracy. 2004. Medical Nutrition Therapy For Anemia. Krause's Food and Nutrition Theraphy. 11th ed. Philadelphia: Saunders.

25. Finalokita, Nesty. 2010. Hubungan antara Status Gizi dan Frekuensi Sarapan Pagi dengan Kadar Hemoglobin Pada Siswi di SMPN 2 Kokap Kabupaten Kulon Progo. Skripsi. Program Studi 
Ilmu Keperawatan Fakultas Kedokteran Universitas Gadjah Mada.

26. Dahlan, M. Sopiyudin. Besar Sampel dan Cara Pengambilan Sampel dalam Penelitian Kedokteran dan Kesehatan Edisi 3. Jakarta: Penerbit Salemba Medika; 2013: 46.

27. Arifin Zainal. 2008. Beberapa Unsul Mineral Esensial Dalam Sistem Biologi Dan Metode Analisisnya. Jurnal Litbang.

28. Dorfman Lisa. 2004. Nutrition For Exercise and Sports Performance. Krause's Food and Nutrition Theraphy. 11th ed. Philadelphia: Saunders.

29. Rolfes Sharon, Pinna Kathryn, Whitney Ellie. 2012. Understanding Normal and Clinical Nutrition. California: Wardsworth.

30. Carbohydrates, Protein, and Fats and Oils: the building blocks of nutrition. Diunduh dari: www.oxfordjournals.org/tropej/online/monts_chap $\underline{3 . p d f}$

31. WHO. Haemoglobin concentrations for the diagnosis of anaemia and assessment of severity. 2011. Vitamin and Mineral Nutrition Information System. Geneva, World Health Organization. 